\title{
OBSERVATIONS ON THE BEAN LACE-BUG IN PORTO RICO
}

\author{
By Mortimer D. Leonard ${ }^{1}$ and Alfres S. Mills"
}

SYSTEMATIC HISTORY

Corythucha gossypii was first deseribed by Fabricius in Ent. Syst. 4, p. 78, 1794 as Acanthia gossypii from the island of Dominica in the West Indies. The species has been subsequently mentioned in systematic literature by Latreille, Burmeister, Herrich-Schaeffer and Fieber, all of whom placed it in the genus Tingis. Stal in 1869 referred it to the genus Galeatus but in 1873 placed it in the genus Corythucha where it has since remained.

\section{DISTRIBUTION AND FOOD-PLANTS}

The bean lace-bug has been recorded from Mexico, New Mexico, Texas, Florida, Central America, from Venezuela in South America and from the West Indies. In the latter it is the most common and widely distributed member of the genus Corythucha, feeding upon several different plants not closely related botanically. It has also been recorded from New York and New Jersey, but according to Barber and Weiss (5) and confirmed by Drake's extensive studies, it does not occur north of Florida. Records from these two states should probably be referred to C. marmorata Uhler.

There follows the detailed distribution data:

Mexico.-In the United States National Museum this species is represented as follows: Specimens from the Uhler collection labelled "Mex."; several from Durango, Feb. 1918; one from Tampico, 1918; Aguas Calientes, one collected by E. A. Schwarz and many specimens collected by F. C. Bishopp, Dec. 1, 1909.

Ferris (16) found the insect in some numbers on castor beans (Ricinus communis) at San José del Cabo in Lower California and Dr. Drake also has material from Lower California. Van Duzee (36) records it from San Carlos Bay, State of Sonora, July 9, breeding in immense numbers on Palo San Juan; also on Coronados Islands, May 18, and on San Esteban Island, April 20. He states that the food-plant is Atamisquaea emarginata.

Dr. Alfons Dampf in a letter dated Feb. 7, 1931 to Dr. C. J. Drake states that this lacebug "appeared in enormous quantity on

${ }^{1}$ Chief Entomologist, Insular Experiment Station, Río Piedras, Porto Rico.

2Junior Plant Quarantine Inspector, United States Department of Agriculture. 
castor beans (Ricinus) sucking the leaves and spoiling the harvest. According to the proprietor the bugs attacked nearly 60 hectares (150 acres) of this plant on the Hacienda El Palmar, between Jalapa and Vera Cruz, State of Veracruz, 700 meters above sea-level."

New Mexico.-Dr. Drake writes that he has one specimen labeled "New Mexico". The United States National Museum has one specimen from the Uhler collection from castor oil without definite locality.

Texas.-Victoria, Dec. 1, 1909, F. C. Bishopp coll. and May 29, 1913 Mitchell and Coad coll. (United States National Museum.)

FLorIDA.-Recorded by Osborn and Drake (25) on Ichthyometia (Piscidia) piscipula, by Watson (37) as injurious to castor bean, and by Blatchley (6) from "Cape Sable and Marco, Feb. 20-Mar. 9, taken by sweeping Hibiscus and other plants along the margins of tidewater bayous. Recorded from Biscayne Bay and Miami." Dr. Drake writes us that he has specimens in his collection from Key West, Miami, Sebring, Gainesville, and Sanford. The United States National Museum has material from Silver Palm, May 15, 1923 (G. F. Moznette collector).

HoNDURAS.-Drake (13) records it as extremely abundant near Tela and considerably injuring sour sop (T. H. Hubbell collector).

Guatemala.-The United States National Museum has 2 specimens from Pantaleon, 1,700 ft. Champion coll, which were recorded as C. decens in Biologia Cent. Am.

Costa RicA.-In the United States National Museum are several specimens from Prunus persica, Dec. 19, 1913, without definite locality.

Panama.-In the United States National Museum many on Jatropha sp. from Bella Vista, Oct. 28, 1918 collected by Dietz and Zetek. Dr. Drake wrote under date of June 11, 1931 that he had recently received material from $\mathrm{Mr}$. Zetek from the Canal Zione who stated that the insect was feeding on beans.

JAMAICA.-Gowdey (19) listed the insect as a pest of Congo pea (Cajanus indicus) and of Hibiscus. The United States National Museum has 2 specimens from Kingston. Van Duzee (33) lists it from Kingston, Mandeville and Montego Bay.

CuBA.-Drake (12) recorded several specimens having been taken at Guines, March 18, 1925, by Dr. J. G. Myers on eastor bean. The United States National Museum has specimens taken on castor oil from Santiago de las Vegas (P. Cardin coll.) May 1918 and San Antonio de los Baños, April 1918. Bruner (7) records it as found 
locally (Aug. 13, 1925) breeding on leaves of citron or cidra (Citrus medica L.) but not important as a pest of this plant.

Harti-Although the insect has apparently not heretofore been recorded from Haiti we have the following statement from Dr. H. L. Dozier, Chief Entomologist of the Department of Agriculture in Haiti under date of March 17, 1931 in which he says "it is common and very abundant, widely distributed everywhere in Haiti on beans and on 'bois cabrit' (Cassia emarginata)." Dr. Wm. A. Hoffman collected 1 specimen at Plaine Cul de Sac, Dumai, April 22, 1925 (United States National Museum).

Santo Domingo.-Many specimens in the United States National Museum from La Romana Central, July 15, 1917, collected by H. Morrison.

PоRто Rico.-The insect is undoubtedly widely distributed in Porto Rico although it is possible that it is confined for the most part to the lower altitudes, not having been recorded as occurring higher than about 1,300 feet (at Cayey).

We have the following definite records mostly from notes in the Insular Experiment Station and from our own observations: in the north part of the Island from Pt. Cangrejos 'on sword bean (Wolcott coll.), 1912 and on beans 1925 (United States National Museum); Camuy, scarce on cotton, 1921; Río Piedras, on sword beans, ( $C a$ navallia spp.) March 1912, Wolcott coll. (United States National Museum); Ciales, on castor bean, 1913; Palo Seco on about two acres of pole lima beans and on several papayas during August, 1930; Río Piedras on lima bean, sour sop (Añona muricata) and on Anona diversifolia Safford, eastor bean and papaya in 1930 and 1931; Mameyes on yautía, 1912; Luquillo on eastor bean 1916; Dr. G. N. Wolcott found several young lemon and orange trees moderately infested in April 1931 at Isabela and the writers early in May made the same observation on young grapefruits at Río Piedras; material in the Drake collection also from Mayagüez; in the south part of the Island from Yauco, scarce on cotton, March 7, 1930; between Yauco and Guánica (Hacienda Santa Rita) on lima beans, badly infested August 21, 1930; Hacienda Santa Rita in Drake collection; Tallaboa, moderate on castor beans, August 21, 1930; Ponce, quite abundant on papaya, July 30, 1930; Guayama, on lima beans, 1917; and Cayey, (about the middle of the Island) quite abundant on papaya, August 2, 1930. We have also found the insect moderately abundant in April and July on eastor bean on Vieques Island both at Puerto Real near the west end and at Salinas on the east end. 
VIrgIN IsLands.-Wilson (40) reports the eastor bean infested with this species on the islands of St. Croix, St. Thomas, and St. John. The same writer (41) also states that C. gossypii is a minor pest of cotton in St. Croix but seriously injures castor beans. We also found it abundant and very injurious in several garden patches of lima beans on the island of St. Thomas on August 11, 1930.

Antigua.-Several specimens in the United States National Museum from castor oil plants on August 19.

Monserrat.-Ballou (1) stated that "a small patch of cotton was attacked by Corythucha the foliage of the plants being affected like that of castor oil plants attacked by the same insect." There seems to be no doubt that this refers to C. gossypii.

ST. Vincent.-Watts (38) says "Corythucha has been noticed feeding on cotton leaves. This is apparently the same insect as that recorded from Monserrat." In Rept. Dept. Agr. St. Vincent for 1919 (39) it is stated that "the Corythucha bug was severe 'on castor oil plants grown at the experiment station during the year." Wilson (41) states it to be a minor pest of cotton. The United States National Museum has material collected by H. H. Smith on the "windward side."

Grenada.- "Grenada" (Drake collection). There is also material in the United States National Museum collected by H. H. Smith from the Mount Gay Estate (leeward side.)

TRINIDAD.-Urich (32) records finding that a "Tingitid, Corythucha near ciliata, also found on the castor bean, seems to have a liking for dahlias, the leaves of which plant it soon causes to wither'". Specimens are in the United States National Museum from castor bean from "Trinidad" collected by F. W. Urich, May 20, 1893 and several collected by W. E. Broadway, Oct. 14, 1908.

Ventzueri.-Several specimens in the United States National Museum from Caracas collected by A. Ernst, Sept. 23, 1886.

Dr. Drake writes that he believes more collecting will greatly extend the distribution of this species in South America.

\section{ECONOMIC IMPORTANCE}

Judging from our own observations and records in literature this insect is by far more injurious to lima beans than to any other of its known food-plants. It has however, apparently not been recorded as attacking lima beans in any place but Porto Rico and the only previous mention of injury to this crop is by Wolcott at Guayama (1916) and by Smyth (1920). On August 11, 1930 a small 
patch of lima beans at Charlotte Amalie in St. Thomas was observed to be badly infested. On August 21, 1930, we saw a small patch of-lima beans at the Hacienda Santa Rita between Yauco and Guánica also badly infested. On August 29, 1930, we visited a grower at Palo Seco, across the bay from San Juan, who had over two acres of pole limas and string beans, the leaves of which were so badly damaged that practically no pods had formed, although the plants were all old enough to have been in full bearing. This grower stated that he had been troubled by the pest for several years and that it was more injurious during the summer, being the main reason why more lima beans were not grown during that season of the year. During the early part of September a severe infestation was observed on a fair sized garden patch of pole limas at Río Piedras on which pod formation had been almost entirely prevented. Two 'or three miles distant another younger planting which waś just starting to blossom was beginning to show the start of an infestation.

It should be mentioned that in September, 1930 a bearing planting of bush limas at Cidra at an altitude of about 1,300 feet showed no infestation and the grower stated that although he had previously grown beans they had never been bothered by the pest.

As is well known the characteristic injury of lace-bugs is caused by the feeding of the nymphs and adults on the underside of the leaves from which they extract the juices. Where only a few insects are present a slight whitish discoloration of the uprer surface is apparent, but as they become more numerous the whitish areas are greater in extent until in severe eases the whole upper surface of the leaf is involved. In some cases the entire surface may be mottled with darker spots and if sufficient feeding has taken place the leaves finally turn brown, wither, and fall off. The under surface becomes spotted and discolored with excrement (Plates XL and XLI). We have noted cases of such severe injury only to lima beans and to the four trees of Anona diversifolia on the Insular Experiment Station grounds mentioned above.

These Anona trees, about five years old, were introduced from Guatemala when about a year old and are about 8-12 feet high. By October and November 1930 the leaves were severely injured and many had dried up and fallen to the ground. By March 1931 these trees had set a new crop of healthy leaves and the lace bugs were scarce. In the case of beans the size and quality of the pods has been reduced or their formation almost entirely prevented. Injury that we have observed to other plants such as cotton, papaya, sour 
sop and citrus has been confined mostly to comparatively small whitish areas on the upper surface of the leaves, altho the grower in Palo Seco where the severe injury to lima beans was observed, stated that twice in the past several years he had experienced considerable injury to his papayas.

\section{LIFE HISTORY AND HABITS}

The bean lace-bug may be found breeding on its various foodplants at all times of the year in Porto Rico. Breeding is continuous and rapid and although the exact length of time needed to complete a generation has not as yet been definitely determined it is apparently not more than about three weeks.

The eggs are laid on the underside of the leaves and are partially inserted into the leaf tissue usually along the midrib but are sometimes laid along the larger veins. They are often deposited within the tissue of the midrib or of the veins. As usual they are surrounded by a mass of black gummy substance which leaves only the cap slightly projecting or which may sometimes almost entirely cover the cap, but frequently eggs may be found projecting a considerable part of their length. A great many eggs may be laid upon a single leaf.

The nymphs usually feed in fairly compact elusters frequentiy in company with one or more adults. Both nymphs and adults are readily disturbed and the colonies tend to seatter when the leaf is turned over for examination.

\section{DESCRIPTION OF STAGES}

The EGG.-(Fig. 1.) Length, .33 mm., greatest width, .15 mm.; flask-shaped with the neck bent somewhat to one side; anterior end

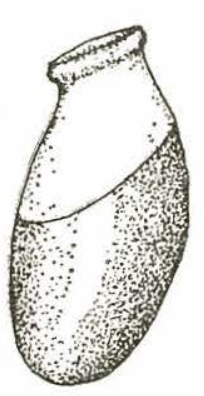

Fig. 1.-Egg obliquely truncate and provided with an oval lid which has a submarginal ridge enclosing a somewhat depressed area; the posterior end rounded; the chorion without sculpture, smooth and shining, the posterior half whitish, the anterior half blackish with the line between the two colors sharply defined

First Stage.-Length .4 mm.; upon hatehing from the egg the nymph is at first pale greenish but the abdomen soon becomes somewhat darker green due to ingested food and the head and thorax begreatiy enlarged. become slightly tinged with brownish; body noticeably cylindrical as compared with the more flattened shape of the 
later stages; antennae only about one third the length of the body and three segmented, last segment with several prominent hairs especially at the tip; eyes consisting of five prominent bright, red ommatidia; a median pair of moderately long black hairs near the front and a pair of longer black hairs on either side on the vertex between the eyes and the median line, each of the latter pair arising from a prominent tubercle; thorax only a little wider than head and with sides almost parallel, slightly brownish along the lateral margin. Pro- and meso-thoracic segments and abdominal segments two to nine with a dark lateral hair and in addition on the meso-thorax there is a median pair; abdominal segments five and six each with a pair of prominent black hairs either side of the median line arranged so as to form a transverse row, segment eight with a pair of median hairs somewhat shorter, each arising from a rather well-defined tubercle and just in front and inside of these, two somewhat shorter black hairs; legs pale yellowish, beak concolorous, with extreme tip distinctly blacker.

SECOND Stage.-Length $.6 \mathrm{~mm}$.; body somewhat more flattened than in first stage and abdomen somewhat more explanate, coloring about the same as in the first stage except that segments four to six of the abdomen contain a little brownish pigment; head with two pairs of simple anterior hairs present in first stage now shorter and arising from an elongated protuberance, the anterior pair of hairs on the vertex also now arises from a prominent blackened conical protuberance, the other pair remaining simple and arising just caudad at their base; thorax distinctly wider than head; the two pairs of lateral hairs on the meso- and meta-thorax are now also much shorter and arise from a darkened conical protuberance; the meso-thorax has a pair of darkened conical protuberanees ending in a short hair and from the base of each arise two simple hairs; the lateral margin of abdominal segments two to nine each with a pale prominent conical protuberance ending in a fine black hair and with a fine black hair arising on the base of each protuberance on abdominal segments two to seven; the two pairs of median black hairs on segments five to six remain the same as in the first stage except that they are shorter but the posterior pair on segment eight is now elongated into two conical protuberances.

THIRD STAGe.-Length $.85 \mathrm{~mm}$; body considerably more flattened than in preceding stage with the lateral margin of the thorax and abdomen distinctly upturned; head, lateral margins of thorax broadly, and dise of abdominal segments four to six more distinctly 
brownish than in preceding stage; conical protuberances on head considerably larger than in preceding stage, dark brownish and the posterior pair of the two cephalio hairs now both arising from a single base which is considerably elevated; thorax with the lateral conical protuberances of the pro- and meso-thorax more prominent than in preceding stage especially those on the meso-thorax; just in front of each is now a small setigerous tubercle and near the base of each two small black hairs; there is a median pair of small hairs on the pro-thorax; abdominal protuberances and hairs appear to be about the same as in the preceding stage except that the second segment now has a pair of pale conical protuberances.

Fourth Stage.-Length $1 \mathrm{~mm}$; number of ommatidia considerably increased, wing pads now distinetly formed, dark brownish, and reaching almost to second abdominal segment; antennae still seem to be but three-segmented; conical protuberances the same as before but those especially on the head and thorax proportionately larger; there are now two pairs of small median hairs on the prothorax; general color of body tending to be a little darker yellow with the brown of the pro-thorax confined to a subquadrate patch on either side of the median line in front and a transverse patch just in front of each wing-pad; the abdomen is now distinctly darkened toward the tip and the antennae are slightly infuscated. toward the tip.

Fifth Stage.-Length 1.5-1.7 mm.; differs chiefly from the preceding stage in the following particulars: eyes have more ommatidia, pro-thorax wider and produced behind into a rounded point on the median line; wing-pads reaching backwards to the fifth abdominal segment and with a prominent lateral angle towards the front; armature on each caudo-lateral angle of pro-thorax consists of two spines, one longer than the other, and a simple hair all arising from a single tubercle; the lateral border of the wing-pads near the middle now has two prominent conical protuberances and a simple hair arising from a common tubercle, second abdominal segment with a pair of median whitish spines tipped with a short fine black hair; the brownish coloring is approximately the same as before on the head, pro-thorax, and abdomen but only the tip and base of the wing-pads are now darkened; antennae now four-segmented.

Adult.-(The following description has been prepared for us by Dr. Carl J. Drake.) Size variable, usually about $3 \mathrm{~mm}$. long and $1.6 \mathrm{~mm}$. wide. The pronotum pale brown; reticulations white 
and marked with brown or fuscous; areolae hyaline. Hood moderately large, slightly contricted behind the middle, rather closely reticulated, more or less marked with brown or fuscous, its length equal to one-half its width. Median earina strongly foliaceous, distinctly arched, subequal to length of hood, mostly biseriate, with a large brown or fuscous spot; lateral carinae rather short, small, raised anteriorly, terminating at base of triangular projection of pronotum, composed of one triangular areola. Antennae testaceous, segments III and IV with numerous long bristly hairs. Bucculae open in front. Mesosternum strongly sulcate, the rostrum extending behind the intermediate coxae.

Body beneath brown to fuscous; legs testaceous. Elytra with sides slightly concave, with distinct tumid elevation, the areolae somewhat variable in size; markings variable, sometimes almost wanting, usually forming two or three interrupted transverse brown to fuscous streaks. Wings a little longer than abdomen. Male claspers strongly curved, slender.

\section{NATURAL ENEMIES}

Although it would seem that the cap of the eggs is sufficiently exposed in most cases to permit of the introduction of parasite eggs, we have reared no egg-parasites nor have any other workers done so as far as we have been able to determine.

The exposed habit of the nymphs should render them an easy target for some of the smaller hymenopterous parasites but apparently this stage is also free from attack.

It is very interesting to note, however, that the larva of a gall midge (Cecidomyidae) has been recorded as attacking a lace-bug nymph in Portugal. This is referred to by H. F. Barnes in a paper entitled "Gall midges (Cecidomyidae) as enemies of the Tingidae, Psylidae, Aleyrodidae and Coccidae"' in Bul. Ent. Res. 21 (3): 319,1930 . The brief reference in full is as follows:

Endopsylla endogena (Kieffer).

Kieffer, Zeits. f. Hymen. u. Dipt. 1, 1907, p. 129-130 (Cecidomyia); Genera Insectorum, fasc. 152, 1913, p. 222 (Endopsylla).

Male and pupa described. Kieffer bred a single male from a dead larva of Stephanitis pyri $F$. Pupation took place inside the Tingid and the adult emerged through a circular hole in the back of the host. The insects were sent by Tavares from Portugal. This species seems to be the most specialized gall midge 
yet known being the only one known to live as an internal parasite and pupate inside its host.

We have found a small black and yellow spider on a considerable number of the leaves of the four trees of Anona diversifolia mentioned above as being badly infested with $C$. gossypii on the Insular Experiment Station grounds at Río Piedras. This spider has been determined by Prof. C. R. Crosby as Theridula opulenta Walckenaer, a cosmopolitan species and according to Petrunkevitch (Trans. Conn. Acad. Sci. 30:189-191, 1930) very common in Porto Rico. It spins a small web on the leaf and in several cases nymphs or adults of the lace-bug have been found caught within it. This spider however is probably not a very important factor in natural control.

A number of adults and nymphs, as well as of the brownish egg-masses of a Reduviid bug, Zelus nugax Stahl, have also been found on the leaves of the same trees. In several instances the nymphs have been observed feeding on those of the lace-bug. This Reduviid has been reported from several localities on the Island as having been found on various plants and trees but no observations have previously been made as to the insects upon which it is predaceous.

\section{CONTROL}

Corythucha gossypii has apparently never been sufficiently abundant on its various economic food-plants to make remedial measures seem worth while except in the case of lima beans.

When we first encountered the severe infestation on lima beans at Palo Seco, mentioned above, the grower told us that he had repeatedly sprayed with nicotine sulphate and soap at standard strengths but with poor success. $\mathrm{He}$ also mentioned that he had had equally poor results with the same combination in the control of the egg-plant lace bug, Corythaica monacha Stahl. A review of the literature dealing with definite experiments on the control of lace-bugs on various plants in various places disclosed the fact that nicotine sulphate was comparatively ineffective even when a small quantity of soap was added as a sticker and spreader. Crosby and Hadley, (Jour. Econ. Ent. 8:409-414, 1915), although they did not use nicotine, state that the rhododendron lace-bug, Stephanitis rhododendri Horvath, (therein discussed under the name of Leptobyrsa explanata Heid.) was found, to be readily controlled by the use of a soap solution, 1 pound in 10 gallons of water. Fink (U. S. D. A. Bul. 239, 1915) conducted a careful series of experiments in 
the control of the egg-plant lace-bug, Gargaphia solani Heid. at Norfolk, Va., in which he carefully tested the comparative merits of soap alone and in combination with various strengths of nicotine sulfate. His results show "That the percentage of nymphs killed was but slightly affected by the increase in the amount of nicotine sulfate and the latter had no effect whatever on the adults; whereas with each increase in the amount of fish-oil soap there was a corresponding increase in the percentage of nymphs killed, until finally we arrive at a'strength which will affect the adults. Above that strength we may then get perfect control of both the nymphs and adults." Fink found that eight pounds of fish oil soap in 100 gallons of water killed 100 per cent of the nymphs and 95 per cent of the adults. Wade (Okla. Agr. Exp. Sta. Bul. 116, 1917) experimenting with the control of the sycamore lace-bug, Corythucha ciliata Say, in Oklahoma obtained results similar to those reported by Fink and found that one pound of fish oil soap in 6 gallons of water gave the most satisfactory kill.

The writers have obtained 100 per cent kill of the nymphs and 95 per cent of the adults by using Octagon soap at the rate of one pound in eight gallons of water. In order to accurately measure the results the total number of nymphs and adults were counted on certain leaves on each plant and checks were left as usual. Care was taken to thoroly wet the underside of each leaf and to apply as nearly as possible a uniform amount of spray material to each plant.

It must be remembered that it is difficult to obtain quite so high a percentage of efficiency in commercial control on account of the difficulty of thoroly wetting the underside of all of the leaves where the insects are clustered. A fine driving mist under comparatively high pressure is essential and the application must be repeated as often as the increasing numbers of the bugs seem to make it necessary.

\section{ACKNOWLEDGMENTS}

The writers wish especially to express their thanks to Dr. Carl J. Drake, Head of the Department of Entomology, Iowa State College, for much assistance in supplying bibliographical and distribution data, the description of the adult insect and checking over the manuscript. Prof. C. R. Crosby of Cornell University has been good enough to send typewritten copies of several references needed. Mr. Harry G. Barber, Curator of Hemiptera, United States National 
Museum was very helpful to the senior author while in the Museum in checking the identity of doubtful specimens in the collection.

\section{BIBLIOGRAPHY}

Following is as complete an index to Corythucha gossypii Fab. in literature as we have been able to find:

1. Ballou, H. A. Report on the prevalence of some pests and diseases in the West Indies during 1914. Part I-Insect Pests. West Indian Bul. 15(2):121-147. 1915.

2. Banks, N. Catalog of nearetic hemiptera-heteroptera, p. 56 . 1910.

Listed as occurring in the Southern States.

3. Barber, H. G. Insects of Florida. II. Hemiptera. Bul. Am. Mus. Nat. Hist. 33, Art. 31:507. 1914.

Listed from Biscayne Bay, Miami, and Key West in Florida.

4.

A preliminary report on the hemiptera-heteroptera of Porto Rico collected by the American Museum of Natural History. Am. Mus. Nov. No. 75:12. 1923. (Merely listed from P. R.)

5. Barber, H. G. and Weiss H. B. The lace-bugs of New Jersey. N. J. Dept. Agr. Bur. Stat. \& Insp. Circ. 54:17. 1922.

Mentioned, but only for the purpose of stating that it does not occur in New Jersey.

6. Blatchley, W. S. Heteroptera or true bugs of Eastern North America with especial reference to the faunas of Indiana and Florida, p. 460, No. 416 (647). 1926.

7. Bruner, S. C. Informe del Departamento de Entomología y Fitopatología. Ejercicio de 1929 a 1930. Est. Exp. Agr. Cuba, p. 48. 1931. (On citron).

8. Burmeister, H. Handbuch der Entomologie, 2:259 1835. (as Tingis).

9. Cotton, R. T. Insects attacking vegetables in Porto Rico. Jour. Dept. Agr. P. R. 2:313. 1918.

Brief mention as a pest of yautía.

10. --_-_- Insectos que atacan las hortalizas en Puerto Rico. Rev. Agr. Puerto Rico 1(6): 267. 1918.

Brief note as yautía pest; nicotine sulphate and soap recommended. 
11. Drake, C. J. On Some North American Tingitidae (Hemip.) Ohio Jour. Sci. 19(7): 418. 1919.

Recorded from cotton, eastor bean, and Ichthyometia (Piscidia) piscipula.

12.

Notes on some Tingitidae from Cuba (Hemiptera). Psyche 33(3): 87. 1926.

Several specimens, Guines, March 18, 1925 on Ricinus communis. Cotton one of preferred hosts.

13. -_._- Some Tingitidae (Heteroptera) from Honduras. Oce. Papers Mus. Zool. Univ. Mich. No. 190, p. 5. 1928.

Extremely abundant near Tela and considerably injuring sour sop.

14. Fabricius, J. C. Entomologia sytematica emendata et aucta secundum classes, ordines, genera, species adjectis synonimis, locis observationes, descriptionibus 4:78. 1794.

Original description as Acanthia gossypii from Dominica.

15. -_-_-_ Systema Rhyngotorum, p. 126. 1803. (as Tingis).

16. Ferris, G. F. Insects of economic importance in the Cape region of Lower California, Mexico. Jour. Econ. Ent. 13(6): 466. 1920.

17. Fieber, F. X. Entomologische monographien (Americae meridionalis insulis), p. 104, pl. 9, fig. 5. 1844. (as Tingis).

Locality given as "Americae meridionalis insulis".

18. Gibson, E. A. The genus Corythucha Stal (Tingidae; Heteroptera). Trans. Am. Ent. Soc. 44:96. 1918.

"Oceurs throughout Southern United States, Central America and West Indies. Common on cotton and has been captured on Icthyometia (Piscidia) piscipula. Numerous specimens have been examined."

19. Gowdey, C. L. Report of Government Entomologist. Jamaica Ann. Rept. Dept. Sci. \& Agr. 1924:19. 1925.

Listed as attacking Congo pea (Cajanus indicus) and Hibiscus.

20. Herrich-Schaeffer, G. A. W. Die wanzenartigen insecten 5:85 fig. 534. 1839. (as Tingis).

21. Jones, T. H. Insects affecting vegetable crops in Porto Rico U. S. D. A. Bul. $192: 4.1915$.

22. Latreille, P. A. Genera crustacearum et insectorum 3:140. 1807. (as Tingis).

23. Leonard, IM. D. Report of the division of entomology for the fiscal year 1929-30 in Rept. Ins. Exp. Sta. P. R. for 1929-30, p. 117.1931. 
24. Lethierry, L. and Severin, G. Catalogue Général Hémiptéres; tome III, p. 11.1893.

As Corythuca; locality Antillae.

25. Osborn, H. and Drake, C. J. Notes on American Tingidae with deseriptions of new species. Ohio Jour. Sci. 17(8):300. 1917.

Taken on Ichthyometia (Piscidia) piscipula in Florida.

26. Smith, J. B. The Insects of New Jersey. Hemiptera. Ann. Rept. N. J. State Mus. for 1909: 148. 1910.

Listed from "Palisades VII, 4, Pt. Pleasant VII, 26 (Bno), but wrongly determined.

27. Smyth, E. G. Cotton insects in Porto Rico. Ent. News 31(5): 124. 1920.

28. Stal, C. Hemiptera Fabriciana 1:93. 1868. (as Galeatus). 29. --_-_-_ Enumeratio Hemipterorum 3:123. 1873. (as Corythucha).

30. Torre-Bueno, J. $\boldsymbol{R}$. de la. Hemiptera Heteroptera of Westches ter County, N. Y. Jour. N. Y. Ent. Soc. 16:232. 1908.

Listed, but the determination was in error.

31. Uhler, P. Check list of hemiptera-heteroptera of North America, p. 22, published by Brooklyn Ent. Soc. 1886.

32. Urich, F. W. Notes on some pest of Trinidad, British West Indies. Ins. Life 6(2): 196. 1893.

33. Van Duzee, E. P. Notes on Jamaican Hemiptera. Bul. Buffalo Soc. Nat. Sci. 8(5):18. 1907.

Listed from Kingston, Mandeville and Montego Bay in Jamaica.

34. - - Check list of the Hemiptera of America, North of Mexico, p. 25. Published by N. Y. Ent. Soc. 1916.

Listed from the Southern States.

35. Catalogue of the Hemiptera of America. North of Mexico, excepting the Aphididae, Coceidae and Aleurodidae. Univ. Calif. Publ. Tech. Bul. Ent. 2:124. 1917.

Bibliography of twelve titles ineluding synonomy.

36.

Expedition of the California Academy of Sciences to the Gulf of California in 1921. The Hemiptera (true Bugs, etc.). Calif. Acad. Sei., 4th Ser., 12:140. 1923.

Listed from San Carlos Bay, Sonora, breeding in numbers on Palo San Juan; Coronados Is., on Atamisquaea emarginata; San Esteban Is. 
37. Watson, J. R. Reports of the Entomologist. Fla. Expt. Sta. Rept. for year ending June 30, 1919:58 R (undated). 1920.

Listed as having been injurious to castor bean leaves during the year.

38. Watts, F. Experiments at the botanic and experiment stations. Rept. Agr. Dept. St. Vincent for 1915-1916:7. 1916.

39. -._-_._. Work connected with insect and fungus pests and their control. Rept. Dept. Agr. St. Vincent for April 1 to Dec. 31, 1919. p. 14.1921.

40. Wilson, C. E. Report of the Entomolıgist. Rept. Virgin Islands Agr. Exp. Sta. for 1920:33. 1921.

41. -_- Insect pests of cotton in St. Croix and means of combating them. Virgin Ids. Expt. Sta. Bul. 3:9. 1923.

Brief note: minor pest of cotton but seriously injures cistor bean.

42. Truck crop insect pests in the Virgin Islands and methods of combating them. Virgin Ids. Agr. Exp. Sta. Bul. 4: 34-35. 1923.

Brief notes on minor injury to tannia (yautia); states favorite foodplant is castor bean; whale oil soap, one pound in five gallons water controlled a severe infestation.

43. Wolcott, G. N. Insectae Portoricensis. Jour. Dept. Agr. P. R. $7(1): 246$. (1923) 1924.

Listed as occurring on several food-plants in several localities in Porto Rico.

44. Entomología Económica Puertorriqueña. Est. Exp. Ins. Puerto Rico. Bol. 32:105-106. 1924.

Brief account as a pest of yautia; recommends nicotine sulphate and soap or soap solution alone.

\section{Explanation of Plates}

Plate XL. Bean leaves showing characteristic yellowing and spotting due to lace bug feeding.

Plate XLI. Bean leaves showing progressive types of feeding injury starting from a healthy leaf (upper left) to a badly yellowed, spotted and dried leaf (lower right). 


\section{PLATE XL.}

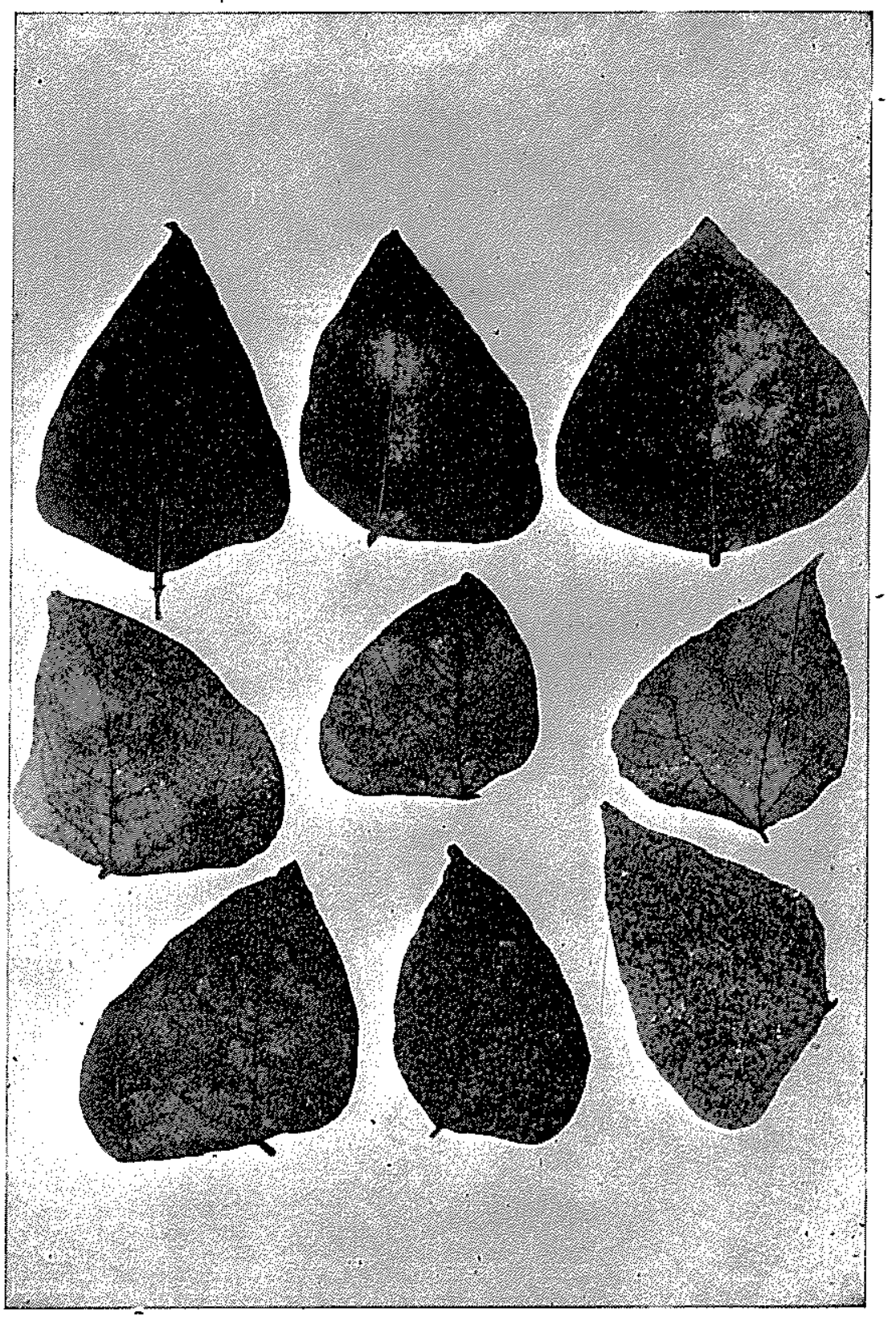




\section{PLATE XLI.}

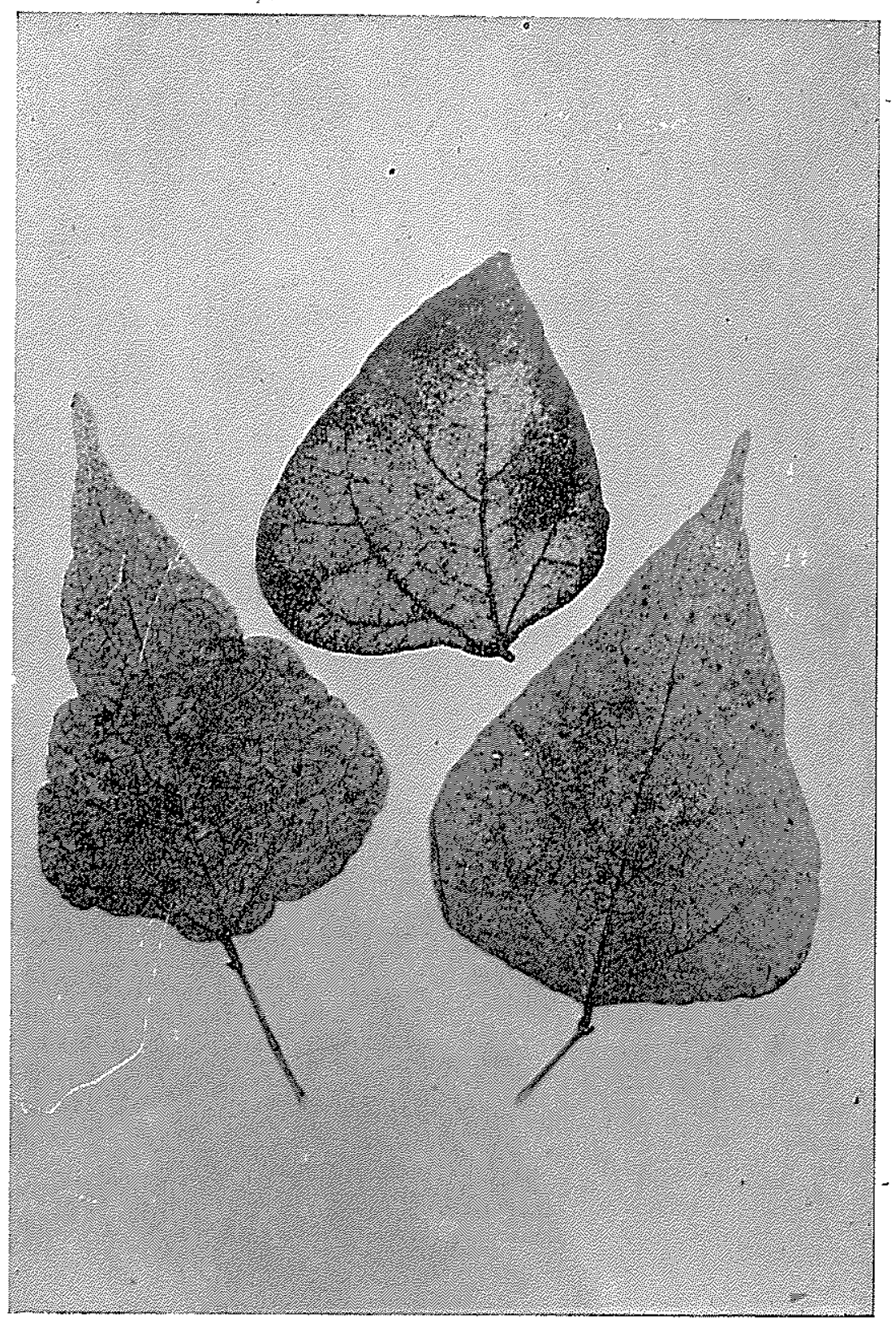

